\title{
INTEROBSERVER VARIATIONS IN DIAGNOSING ASBESTOSIS ACCORDING TO THE ILO CLASSIFICATION
}

\author{
Irena PERIĆ ${ }^{1}$, Katarina NOVAK ${ }^{1}$, Igor BARIŠIĆ ${ }^{1}$, Kornelija MIŠE ${ }^{1}$, Maja VUČKOVIĆ ${ }^{1}$, \\ Stipan JANKOVIĆ ${ }^{1}$, and Jadranka TOCILJ ${ }^{2}$ \\ University Hospital of Split and School of Medicine ${ }^{1}$, Faculty of Natural Sciences, Mathematics and Kinesiology², \\ University of Split, Split, Croatia
}

Received in August 2008

Accepted in March 2009

\begin{abstract}
Inhalation of asbestos fibres leads to asbestosis of the pleura and the lung, with possible progression to lung cancer and malignant pleural or peritoneal mesothelioma. Asbestosis remains difficult to diagnose, especially in its early stages. The most important role in its diagnosis is that of chest radiographs. The aim of this cross-sectional study was to address interobserver variations in interpreting chest radiographs in asbestos workers, which remain to be an issue, despite improvements in the International Labour Office (ILO) classification system. In our ten-year study, we investigated 318 workers occupationally exposed to asbestos, and in 210 workers with diagnosed asbestos-related changes we compared interpretations of chest radiographs according to ILO by two independent radiologists. The apparent degree of interobserver variation in classifying lung fibrosis was $26.66 \%$ for the diameter of changes and $42.2 \%$ for the profusion of the changes. In cases with diffuse pleural thickening, the interobserver variation using ILO procedures was $34.93 \%$. This investigation raises the issue of standardisation and objectivity of interpretation of asbestosis according to the ILO classification system. This study has revealed a significant disagreement in the estimated degree of pleural and parenchymal asbestos pulmonary disease. This is why we believe highresolution computed tomography (HRCT) should also be used as a part of international classification.
\end{abstract}

KEY WORDS: asbestos, chest radiography, interobserver variability, occupational exposure

Asbestosis is a pneumoconiosis caused by long-term inhalation of asbestos fibres, usually due to occupational exposure. The diagnosis of pleural and pulmonary asbestosis is usually based on chest radiography and information about professional exposure to asbestos (1-3). Non-malignant diseases can involve pulmonary asbestosis, pleural plaques and/or diffuse pleural thickening, pleural effusion, and rounded atelectasis (folded lung) (2-4). Histolopathologically, asbestosis is a peribronchiolar and interstitial fibrosis under the parietal pleura of the lateral chest wall (5). Recent data have confirmed that asbestosis can be present histopathologically even though high-resolution CT scan may be normal or near normal (6).
Usually, the degree of asbestosis is evaluated by at least two expert observers who interpret conventional chest radiographs according to the International Labour Organization (ILO) Classification. During the 1960s, ILO classification was revised to include pleural changes and symbols for linear or irregular patterns. Recent modifications related to pleural changes do not distinguish between visceral and parietal pleural lesions. The 2000 revision of the ILO Classification defines that diffuse pleural thickening on chest radiographs has to be at least $3 \mathrm{~mm}$ thick. However, interobserver variation seems to be a substantial problem in interpreting chest radiographs of asbestos-exposed workers (7-9). Ducatman studied 
interobserver variations in ILO interpretations of asbestos-workers' X-rays. His recommendations include participation in quality assurance panels for those who wish to be certified as interpreters (10). This would ensure that classification achieves its intended epidemiological purposes.

High-resolution computed tomography (HRCT) has proved to be a simple, reliable, and reproducible method for classifying lung fibrosis and diagnosing asbestosis, and it would be possible to use it as a part of an international classification $(11,12)$. Gamsu found that high-resolution CT scans had a higher detection rate for interstitial fibrosis than chest radiographs classified according to the ILO classification in occupationally exposed population (6).

The aim of this cross-sectional study was to establish variability between two radiologists in interpreting diffuse pleural thickening and small lung opacities in patients with asbestosis.

\section{SUBJECTS AND METHODS}

We examined 318 workers who had worked with asbestos for at least five years in three factories in the Dalmatian region: Salonit asbestos cement factory in Vranjic, the factory of asbestos products Plobest Ploče, and a shipbuilder in Split (BIS). Table 1 shows the distribution of subjects with respect to their occupation. Among the 318 subjects, 242 (76\%) were men (median age: 53 years; range: 35 to 74 years) and 76 (24\%) women (median age: 49 years; range: 31 to 62 years). All workers were clinically examined, including cardiological and other necessary examinations. Of the total number of subjects initially involved in the study, 108 were excluded due to unknown reasons (33 subjects), arterial hypertension
(29 subjects), COPD (23 subjects), malignant disease (12 subjects), or myocardiopathy (11 subjects). The remaining population included 210 workers. All of them were taken chest radiographs in the frontal, lateral, and oblique projections using the high-voltage technique. The study included chest radiographs only of subjects with verified diffuse pleural thickening $(\mathrm{N}=83)$ and small lung opacities $(\mathrm{N}=90)$. Each radiograph was interpreted and coded by two independent radiologists with proficiency in classifying chest radiographs for pneumoconioses using ILO classification (3).

\section{RESULTS AND DISCUSSION}

Interpretations performed by two independent Xray readers are summarised in Figures 1-3. Variation between the two observers in the interpretation of the diameter of small lung opacities was $26.66 \%$ (Figure 1) and was even higher in the interpretation of their profusion, $42.22 \%$ (Figure 2). The concordance between histopathologically confirmed asbestosis and chest radiographs defined by an ILO grade of $1 / 0$ or greater was $48 \%$, which is similar to data published earlier (6). In the interpretation of diffuse pleural thickening in the craniocaudal view, the interobserver variation was $34.93 \%$ (Figure 3). Of all pathologically documented asbestos-related pleural plaques or asbestoses chest radiography was able to detect only $40 \%$ to $60 \%$. About $15 \%$ of occupationally exposed individuals who demonstrated radiographic abnormalities consistent with asbestosis, showed no visible pleural plaques on radiographs. Autopsy studies have shown that pleural plaques are much more common than asbestosis and are present in most asbestosis cases, but may be too small to be seen on radiographs $(6,12-13)$.

Table 1 Distribution of study subjects according to occupation

\begin{tabular}{lccc}
\hline \multirow{2}{*}{ Factory } & Type of asbestos production & \multicolumn{2}{c}{ Subjects of study / No. (\%) } \\
\cline { 3 - 4 } & Asbestos cement factory & $\begin{array}{c}\text { At the beginning } \\
\text { of the survey }\end{array}$ & $\begin{array}{c}\text { At the end } \\
\text { of the survey }\end{array}$ \\
\hline Salonit Vranjic & Factory of asbestos products & $126(40 \%)$ & $83(40 \%)$ \\
Plobest Ploče & Shipbuilder industry & $139(44 \%)$ & $90(43 \%)$ \\
BIS Split & & $53(17 \%)$ & $37(18 \%)$ \\
\hline Total & & 318 & 210 \\
\hline
\end{tabular}


Our results are in accordance with previous reports. In a study which included 551 chest radiographs reinterpreted by six independent consultants in chest radiology, Gitlin et al. (14) concluded that the difference between interpretations by initial readers and reinterpretations was too great to be attributed to interobserver variability. It has to be stressed, however, that in most cases the reinterpretations of small opacity profusions were more accurate than those reported by initial readers (14-17).

The most apparent disadvantage of the International Labour Office (ILO) classification system is that it cannot clearly distinguish diffuse pleural thickening from subpleural fat and prominent intercostal muscles (16). Pleural plaques are a specific type of asbestosinduced pleural disease. However, diffuse pleural thickening is not precisely defined in radiological terms. As ILO Classification does not distinguish

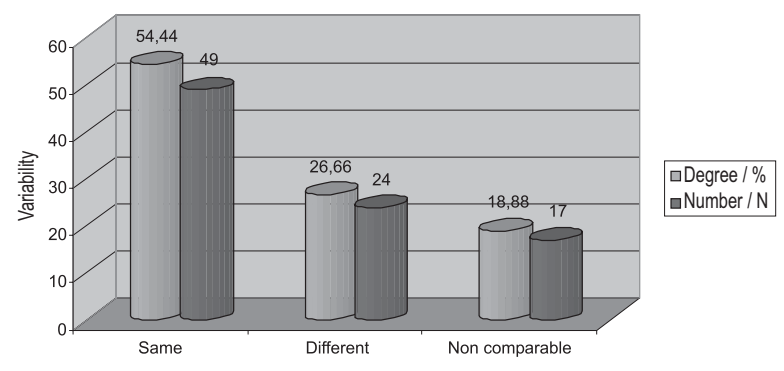

Figure 1 Interobserver variability in classifying the diameter of small lung opacities according to ILO

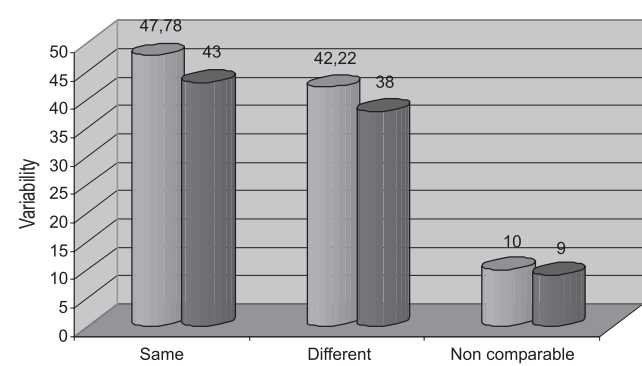

$\square$ Degree $/ \%$ $\square$ Number / N

Figure 2 Interobserver variability in classifying the profusion of small lung opacities

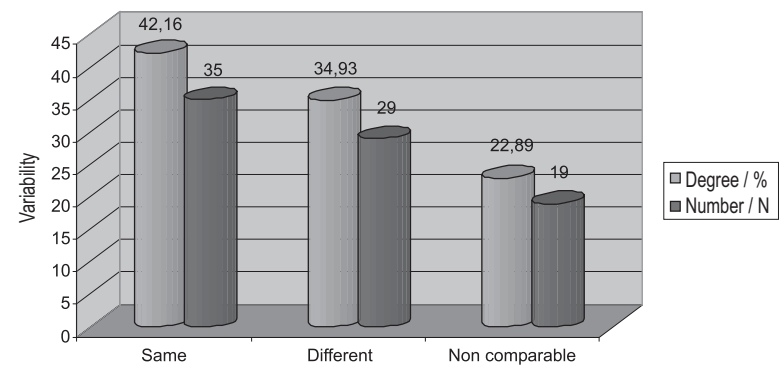

Figure 3 Interobserver variability in classifying diffuse pleural thickening according to ILO between lesions located on the visceral from those on the parietal pleura, this may also be a potential source of confusion (11). There are two main definitions of diffuse pleural thickening on chest radiographs. According to Mc Loud et al. (18) it is a smooth, uninterrupted pleural density extending over at least one fourth of the chest wall, associated or not with costophrenic blunting. On the other hand, Lynch et al. (19), defined diffuse pleural thickening on CT scans as a continuous sheet of pleural thickening more than 5 $\mathrm{cm}$ wide, more than $8 \mathrm{~cm}$ in craniocaudal extent, and more than $3 \mathrm{~mm}$ thick.

Interobserver variation in interpreting diffuse pleural thickening in this study was possibly caused by subpleural fat and prominent intercostal muscles, which may be misinterpreted as pleural disease.

In his evaluation, Ducatman (10) says that the apparent degree of agreement/variability between observers is affected by the prevalence of a disease in a population. He also believes that experts agree routinely about the interpretation of normal films. However, Epler et al. (20) reported that in a number of subjects with apparently normal films, subsequent biopsies confirmed chronic diffuse infiltrative lung disease. Frumkin et al. (21) also found a considerable inter-reader variability. The average sensitivity in their study was 0.32 , and decreasing film quality was associated with decreasing sensitivity, but specificity was not affected by film quality.

Our observations show that two independent observers disagreed about the profusion in $42.22 \%$ and about the diameter of fibrosis lines or dense bands in $26.66 \%$ of parenchymal asbestosis cases. Similarly, Friedman et al. (22) found that positive predictive value for parenchymal disease was $51 \%$ for outside films, $83 \%$ for inside films, and $100 \%$ for HRCT.

We also noted a great interobserver variability in the interpretation of pleural and parenchymal asbestosis. Several strategies have been proposed to overcome interobserver variability. One is obligatory participation in quality assurance panels for those who wish to be certified interpreters. In addition, HRCT gives the radiologist greater confidence in diagnosing asbestos-induced pleural and parenchymal disease $(7-10,17-23)$. In conclusion, we found the ILO classification system insufficient, mainly due to a significant difference in establishing pleural and parenchymal asbestos-induced disease. We therefore propose that high-resolution CT be used to assess a number of suspicious abnormalities, as HRCT is superior to the ILO classification in diagnosing asbestosis. 


\section{REFERENCES}

1. Perić I, Tocilj J, Batina S, Barišić I, Goić-Barišić I. Asbestosis - physical examination and symptoms. Acta Med Croat 2007;61:421-4.

2. Felton JS, Sargent EN, Gordonson JS. Radiographic changes following asbestos exposure: Experience with 7.500 workers. J Occup Med 1980;22:15-20.

3. Perić I. Retrospektivna analiza epidemioloških, funkcionalnih i radioloških podataka kod azbestne bolesti pluća i plućne maramice [Retrospective analysis of function, clinical and radiographic changes in lung and pleural asbestosis, in Croatian]. [PhD thesis]. Zagreb: Medical School, University of Zagreb; 2002.

4. Bateman ED, Benatar SR. Asbestos-induced diseases: clinical perspectives. Q J Med 1987;47:292-7.

5. Mossman BT, Gee JBL. Asbestos-related diseases. N Engl J Med 1989;320:1721-30.

6. Gamsu G, Salmon CJ, Warnock ML, Blanc PD. CT Quantification of interstitial fibrosis in patients with asbestosis: A comparison of two methods. AJR Am J Roentgenol 1995;164:63-8.

7. International Labour Office (ILO). Guidelines for the use of the ILO international classification of radiographs of pneumoconiosis, revised edition 1980. Occupational Safety and Health Series No. 22, Geneva: ILO; 1980.

8. Miller A. Radiographic readings for asbestosis: misuse of science - validation of the ILO classification. Am J Ind Med 2007;50:63-7.

9. Lee VC, Singh B, Pang SC, de Klerk NH, Hillman DR, Musk AW. Radiographic (ILO) readings predict arterial oxygen desaturation during exercise in subjects with asbestosis. Occup Environ Med 2003; 60: 201-6.

10. Ducatman AM. Variability in interpretation of radiographs for asbestosis abnormalities: problems and solutions. Ann NY Acad Sci 1991;643:108-20.

11. Gevenois PA, De Maertelaer V, Madani A, Winant C, Sergent G, De Vuyst P. Asbestosis, pleural plaques and diffuse pleural thickening: three distinct benign responses to asbestos exposure. Eur Respir J 1998;11:1021-7.

12. American Thoracic Society (ATS). Medical Section of the American Lung Association: the diagnosis of nonmalignant diseases to asbestos. Am Rev Respir Dis 1986;134:363-8.
13. Muller JG, Rudolph WG, Lieske JM, Hernandez JE, Jan MH, Kubiak G. Changes in B-readings over time in the United States Navy Asbestos Medical Surveillance Program. J Occup Environ Med 2007;49:194-203.

14. Gitlin JN, Cook LL, Linton OW, Garrett-Mayer E. Comparison of "B" readers' interpretations of chest radiographs for asbestos related changes. Acad Radiol 2004;11:843-56.

15. Muller JG, Lieske JM, Hernandez JE, Kubiak G, Rudolph WG, Jan MH. Variability in interpretation among B-readers in the U.S. Navy Asbestos Medical Surveillance Program. Mil Med 2008;173:375-80.

16. Huuskonen O, Kivisaari L, Zitting A, Taskinen K, Tossavainen A, Vehmas T. High- resolution computed tomography classification of lung fibrosis for patients with asbestos-related disease. Scand J Work Environ Health 2001;27:106-12.

17. Gevenois PA, de Maertelaer V, Madani A, Winant C, Sergent G, De Vuyst P. Asbestosis, pleural plaques and diffuse pleural thickening: three distinct benign responses to asbestos exposure. Eur Respir J 1998;11:1021-7.

18. McLoud TC, Woods BO, Carrington CB, Epler GR, Gaensler EA. Diffuse pleural thickening in an asbestos exposed population: prevalence and causes. AJR Am J Roentgenol 1985;144:9-18.

19. Lynch DA, Gamsu G, Aberle DR. Conventional and high resolution computed tomography in the diagnosis of asbestosrelated diseases. Radiographics 1989;9:523-51.

20. Epler GR, McLoud TC, Gansler EA, Mikus JP, Carrington CB. Normal chest roentgenograms in chronic diffuse infiltrative lung disease. N Engl J Med 1978;298:934-9.

21. Frumkin H, Pransky G, Cosmatos I. Radiologic detection of pleural thickening. Am Rev Respir Dis 1990;142:132530.

22. Friedman AC, Fiel SB, Fischer MS, Redecki PD, Lev-Toaff AS, Caroline DF. Asbestos-related pleural disease and asbestosis: A comparison of CT and chest radiography. AJR Am J Roentgenol 1988;150:269-75.

23. Vujović M, Vujović I, Kuzmanić I. The application of new technologies in diagnosing occupational asbestosis. Arh Hig Rada Toksikol 2003;54:245-52. 
Sažetak

\title{
INTEROPSERVACIJSKE RAZLIKE U DIJAGNOSTICIRANJU AZBESTOZE PREMA KLASIFIKACIJI ILO
}

\begin{abstract}
Azbestoza je bolest koja nastaje kao posljedica inhalacije azbestnih vlakana. Zahvaća pluća i pleuru, a ponekad može dovesti do karcinoma pluća, pleure i peritoneuma. Azbestozu je teško dijagnosticirati, osobito u početnom stadiju bolesti. U dijagnostici azbestoze presudna je radiološka obrada. Cilj ovog rada je utvrditi interopservacijske razlike $u$ analizi radiograma prema kriterijima klasifikacije ILO kod profesionalne azbestoze. U istraživanje je bilo uključeno 318 ispitanika profesionalno izloženih azbestnim česticama. U 210 ispitanika kojima je postavljena dijagnoza azbestoze usporedili smo radiološke nalaze analizirane od dvaju neovisnih radiologa eksperata u skladu s važećom klasifikacijom ILO. Uspoređujući rezultate analize malih zasjenjenja parenhima pluća prema njihovoj veličini, našli smo da se rezultati razlikuju u 26,66 \% slučajeva, dok je prema prožetosti intersticija neslaganje bilo još učestalije, tj. zabilježeno je u 42,22 \% slučajeva. U ispitanika s pleuralnim promjenama usporedili smo rezultate analize difuznih pleuralnih zadebljanja i našli neslaganje u debljini i/ili širini pleuralnih zadebljanja u $34,93 \%$ slučajeva. Uočili smo značajno neslaganje u procjeni stupnja azbestne bolesti na pleuri i na parenhimu pluća. Zbog toga smatramo da je u kvantificiranju promjena izazvanih azbestom i u procjeni stupnja tjelesnog oštećenja nužno rabiti kompjutoriziranu tomografiju visoke rezolucije kao znatno osjetljiviju i pouzdaniju slikovnu tehniku.
\end{abstract}

KLJUČNE RIJEČI: azbest, interopservacijske razlike, profesionalna izloženost, radiološki nalaz

\section{CORRESPONDING AUTHOR:}

Irena Perić, $\mathrm{MD}, \mathrm{PhD}$

M. Krleže 26, HR-21000 Split, Croatia

E-mail: irena.peric1@st.t-com.hr 